The International Journal of Indian Psychology: Volume: 01 | Issue: 04 | ISSN 2348-5396

\title{
Effect of Mindfulness and Cognitive Behavior Therapy on Conduct and Scholastic Problems of Marginalized Children
}

\author{
Dr. D. S. Charan*
}

\begin{abstract}
:-
The Purpose of the study is to measure Intelligence ability and social intelligence of students and thus we know that where should they stand in world of today and prepare them for World of Tomorrow. For this researcher has decided to Organize standardize social intelligence test for study interaction measures of Intelligent ability and social intelligent on scholastic achievement for standard IX students of Dahod Taluka, in Dahod District.

Intelligence is a property of mind that encompasses many related abilities such is the capacities to reason to plan, to solve problems, to think abstractly, to comprehend ideas, to use languages and to learn. Even in some cases intelligence may include traits such as creativity, personality, character knowledge or wisdom.
\end{abstract}

Types of Intelligence is classification are made by 'Thorndike (1927)

a) Concrete Intelligence b) Abstruct Intelligence c) social Intelligence

According to spearman (1923), "Intelligence is which involves mainly the education of relations and correlation" Are all people equally intelligent? Are all the students fit for school instruction? No, But only some persons are intelligent, they Stands First in Class exam and they will some more marks.

Schooling is an important factors that affecting intelligence. Children who do not attend school or who attend intermittently score more poorly on IQ tests than those who attend regularly and Children who move from low quality schools to high quality school tend to show improvement in I.Q. Besides transmitting information to students directly, school teach problem solving, abstract thinking and how to question attention all skills required on IQ tests.

\section{Introduction}

The present educational system does not give guarantee for a successful life. The person with high intellect cannot be always successful. A vacuum is realized over the years. Many have been tried to till the gap between the success and failure caused by mind and heart.

*Y. S. Arts \& K. S. Shah Commerce College, Devgadh Baria, Dist.Dahod (Gujarat) 


\section{The International Journal of Indian Psychology: Volume: 01 | Issue: 04 | ISSN 2348-5396}

The present study continues on the same Line. The advancement in science \& technology need an individual to development skills and competence to scope the extenal demand. The success and chances of a productive life of a student are directly dpended on social intelligence and intelligence Ability. Survival in today's competive world is something, which cannot be determined by the intellect alone, continued existence in such and unpredictable environment calls for the mutual functioning of the intellect, emotions and the method of coping with daily stress and demands. Smita singh \& Bala koteswari, Edutracks August(2006) . Therefore, the present study is conducted to explore the interaction effect of intelligence ability and social intelligence on scholastic achievement of secondary schools students.

Objectives of the study:

- To study the impact of intelligence ability and social intelligence on scholastic achievement of student of the standard IX.

- To study the impact of intelligence and social intelligence on scholastic achievement of their area of intrest in standard IX students .

- To study the impact of intelligence ability and social intelligence on the scholastic achivement of their gebder of students of the standard IX.

Hypothesis of the study:

The falling null hypothesis will be formulated for the present study.

- There will be no significant impact in the mean score of intelligence ability and social intelligence ability on scholastic achievement of students of standard IX

- There will be no significant impact in the mean score of intelligence and social intelligence on scholastic achievement of rural and urban students.

- There will be no significant impact in the mean score of intelligence and social intelligence on scholastic achievement of boys and girls students of standard IX

Variable of the Study

(A) Independent variables

1 Intelligence ability

2 Social Intelligence

3 Gender

4 Area 


\section{The International Journal of Indian Psychology: Volume: 01 | Issue: 04 | ISSN 2348-5396}

(B) Dependent variables

1 Scholastic achievement

Delimitation of the Study

This study is restricted only for the students who enrolled to standard IX during the academic year-2012-13 in GSEB grant -in-aid secondary schools offering education through Gujarati medium of Dahod taluka in Dahod district.

Sample

The investigator selected the sample by using simple random sampling method and stratified random sampling method. The sample of the study consists of 296 students of IX standard studying in different area of schools of Dahod taluka which includes 136 boys and 160 girls.

Methodology of the Study

The methodology adopted in the present study to achieve the stated objectives was survey method.

Tools Used For Data Collection

The following standardized tests were used for data collection.

Intelligence ability

For the purpose of measuring ability of IX standard students, the researcher used the Desai's Verbal and non-verbal Group intelligence test designed and developed by Dr. K.G.Desai Social Intelligence

For the purpose of measuring social intelligence of standard IX students, the researcher used the social intelligence scale designed and developed by Dr. N.K.Chadda and Ms. Usha Gianeshan (2004)

\section{Scholastic Achievement}

For the purpose of measuring scholastic Achievement of student of standard IX, the researcher collected the result of first semester exam of students of standard IX in year 2012-13. Data Analysis and Interpretation:

Following statistical techniques were used for the data analysis and interrelation

○ F- test 
The International Journal of Indian Psychology: Volume: 01 | Issue: 04 | ISSN 2348-5396

Testing of null hypotheses:

HO1:

There will be no significant impact in the mean score of intelligence ability and social intelligence ability on scholastic achievement of students of standard IX.

Table - 1

Impact in the mean score of Intelligence ability and social Intelligence on scholastic achievement

$(\mathrm{N}=296)$

\begin{tabular}{|l|l|l|l|l|l|}
\hline S V & DF & SS & MS & F-Value & Significance \\
\hline Main Impacts & & & & & \\
\hline $\begin{array}{l}\text { Intelligence } \\
\text { Ability }\end{array}$ & 1 & 2067.90 & 2067.90 & 29.52 & $S^{*}$ \\
\hline $\begin{array}{l}\text { Social } \\
\text { Intelligence }\end{array}$ & 1 & 585.20 & 585.21 & 8.35 & S* \\
\hline $\begin{array}{l}\text { Interaction } \\
\text { Way }\end{array}$ & & & & & \\
\hline $\begin{array}{l}\text { Intelligence X } \\
\text { Social }\end{array}$ & 1 & 187.90 & 187.90 & 2.68 & NS \\
\hline Intelligence & & & & & \\
\hline Error & 292 & 20455 & 70.05 & & \\
\hline
\end{tabular}

* Significant at 0.01 Level of Significance.

The above null hypothesis is tested using the data presented in the table...1

It is observed from the table - 1 that the $\mathrm{F}$ - value 2.68 is smaller than table value at both

0.05 and 0.01 Level of significance. Therefore, the null hypothesis is accepted so, the F-value found to be not significant Hence, it is inferred there is no significant impact in the mean score of intelligence ability and social intelligence on scholastic achievement of students of standard IX. Table -2

Impact in the mean score of intelligence ability and social Intelligence on scholastic achievement of rural area students 
The International Journal of Indian Psychology: Volume: 01 | Issue: 04 | ISSN 2348-5396

(Rural Area students-108)

\begin{tabular}{|l|l|l|l|l|l|}
\hline S V & DF & SS & MS & F-Value & Significance \\
\hline Main Impacts & & & & & \\
\hline $\begin{array}{l}\text { Intelligence } \\
\text { Ability }\end{array}$ & 1 & 245.75 & 245.75 & 4.72 & $5 * *$ \\
\hline $\begin{array}{l}\text { Social } \\
\text { Intelligence }\end{array}$ & 1 & 83.69 & 83.69 & 1.600 & N S \\
\hline $\begin{array}{l}2 \quad \text { Way } \\
\text { Interaction }\end{array}$ & & & & & \\
\hline $\begin{array}{l}\text { Intelligence } \\
\text { Ability X }\end{array}$ & 1 & 0.0643 & 0.0643 & 0.00122 & NS \\
\hline $\begin{array}{l}\text { Social } \\
\text { Intelligence }\end{array}$ & & & & & \\
\hline Error & 104 & 5414.13 & 52.05 & & \\
\hline
\end{tabular}

** Significant at 0.05 level of Significance

There will be no significant impact in the mean score of Intelligence ability and social intelligence ability on scholastic achievement of rural students of standard IX.

The above null hypothesis is tested using the data presented in the table -2 , it is observed from the table -2 that the $\mathrm{F}$ - value 0.00122 is smaller than table value at both 0.05 and 0.01 level of Significance. Therefore, the null hypothesis is accepted, so, the F- value found to be not significant impact in the mean score of intelligence ability and social Intelligence on scholastic achievement at rural students at standard IX.

TABLE -3

Impact in the mean score of Intelligence ability and social Intelligence on scholastic achievement of urban students $(\mathrm{N}=188)$

\begin{tabular}{|l|l|l|l|l|l|}
\hline S V & DF & SS & MS & F-Value & Significance \\
\hline Main Impacts & & & & & \\
\hline Intelligence Ability & 1 & 2633.81 & 2633.81 & 30.93 & $5^{*}$ \\
\hline Social Intelligence & 1 & 766.83 & 766.83 & 8.72 & $5^{*}$ \\
\hline
\end{tabular}


The International Journal of Indian Psychology: Volume: 01 | Issue: 04 | ISSN 2348-5396

\begin{tabular}{|l|l|l|l|l|l|}
\hline $2-$ Way Interaction & & & & & \\
\hline Intelligence Ability X & 1 & 455.12 & 455.12 & 5.27 & $5^{* *}$ \\
\hline Social Intelligence & & & & & \\
\hline Error & 184 & 16188.31 & 87.97 & & \\
\hline
\end{tabular}

* Significant at 0.01 level, * * significant at 0.05 level.

There will be no significant impact in the mean score of intelligence ability and social intelligence ability on scholastic achievement of urban students of students IX.

The above null hypothesis is tested using the data presented in the table - 3. It is observed from the table -3 that the $\mathrm{F}$ - value 5.27 is greater than table value of 0.05 level of significance. Therefore, the null hypothesis is rejected. So, the F- value found to be significant. Hence, it is inferred that there is significant impact in the mean score of intelligence ability and social Intelligence on scholastic achievement of urban students of standard IX.

TABLE -4

Impact in the mean score of Intelligence and social Intelligence on scholastic achievement.

(Boys students - 136)

\begin{tabular}{|l|l|l|l|l|l|}
\hline S V & DF & SS & MS & F-Value & Significance \\
\hline Main Impacts & & & & & \\
\hline $\begin{array}{l}\text { Intelligence } \\
\text { Ability }\end{array}$ & 1 & 433.8 & 433.8 & 6.195 & $5^{* *}$ \\
\hline $\begin{array}{l}\text { Social } \\
\text { Intelligence }\end{array}$ & 1 & 187.23 & 187.23 & 2.67 & NS \\
\hline $\begin{array}{l}2 \quad \text { Way } \\
\text { Interaction }\end{array}$ & & & & & \\
\hline $\begin{array}{l}\text { Intelligence } \\
\text { Ability X }\end{array}$ & 1 & 25.44 & 25.44 & 0.36 & NS \\
\hline $\begin{array}{l}\text { Social } \\
\text { Intelligence }\end{array}$ & & & & & \\
\hline Error & 132 & 9243.12 & 70.02 & & \\
\hline
\end{tabular}

$* *$ significant at 0.05 level of significance 


\section{The International Journal of Indian Psychology: Volume: 01 | Issue: 04 | ISSN 2348-5396}

There will be no significant impact in the mean score of Intelligence ability and social Intelligence ability on scholastic achievement of boys of standard IX.

The above null hypothesis is tested using the data presented in the table -4 . It is observed from the table -4 that the $\mathrm{F}$ - value 0.36 is smaller than table value as both 0.05 and 0.01 level of significance. Therefore the null hypothesis is accepted so, the F - value found to be not significant. Hence, it is inferred that there is no significant impact in the mean score of intelligence ability and social Intelligence on scholastic Achievement of boys of standard IX.

TABLE - 5

Impact in the mean score of Intelligence ability and social Intelligence on scholastic achievement of Girls Students (Grits students - 160)

\begin{tabular}{|l|l|l|l|l|l|}
\hline S V & DF & SS & MS & F-Value & Significance \\
\hline Main Impacts & & & & & \\
\hline Intelligence Ability & 1 & 1082.43 & 1082.43 & 22.036 & S* \\
\hline Social Intelligence & 1 & 180.18 & 180.18 & 3.66 & NS \\
\hline 2- Way Interaction & & & & & \\
\hline Intelligence Ability X & 1 & 633.21 & 633.21 & 12.89 & S* ct \\
\hline Social Intelligence & & & & & \\
\hline Error & 156 & 7663.92 & 49.12 & & \\
\hline
\end{tabular}

There will be no significant impact in the mean score of intelligence ability and social intelligence ability on scholastic achievement of girls of standard IX.

The above null hypothesis is tested using the data presented in the table -5 It is observed from the table - 5 that the $\mathrm{F}$ - value 12.89 is greater than table value at 0.01 level of significance. Therefore. The null hypothesis is rejected. So, the F - value found to be significant. Hence, it is inferred that there is significant impact in the mean score of intelligence ability and social Intelligence on scholastic achievement of girls of standard IX.

\section{MAJOR FINDING}

- Intelligence ability has significant impact on the scholastic achievement of students of standard IX.

- Social Intelligence has significant impact on the scholastic achievement of students of standard IX. 


\section{The International Journal of Indian Psychology: Volume: 01 | Issue: 04 | ISSN 2348-5396}

- Intelligence ability and social Intelligence do not have significant impact on the scholastic Achievement of students of standard IX.

- Intelligence Ability has significant impact on the scholastic achievement of rural area students of standard IX.

- $\quad$ Social Intelligence does not have significant impact on the scholastic Achievement of Rural area students of standard IX.

- Intelligence Ability and social Intelligence do not have significant impact on the scholastic Achievement of rural area students of standard IX

- Intelligence Ability and social Intelligence have significant impact on the scholastic achievement of urban area Students of standard IX.

- Intelligence Ability and social Intelligence do not have significant impact on the scholastic Achievement of boys of standard IX.

- Intelligence Ability and social Intelligence have significant impact on the scholastic Achievement of girls of standard IX.

\section{SUGGESTIONS}

- $\quad$ Research may be undertaken by taking large sample

- $\quad$ Study may be conducted by including the students of English medium

- $\quad$ study may be conducted by including variables like emotional intelligence, adjustment, personality, attitude etc.

- $\quad$ Study may be conducted by including the sample from VIII standard, X standard etc..... REFERENCES

1. Barton K Dielman T. E. \& cattle R. B. (1972) “personality and IQ measures as predictors of school achievement Journal of educational psychology, 64(4)398-400

2. chadda N. K. and Usha Ganeshan (2004), Menual for social Intelligence scale, National psychological corporation, Agra

3. Desai K. G. (1992), Institne of psychology and Edu. Research and Guidance, Ahmadabad

4. Kuppuswamy B.(1995),’Elements of social psychology” konark publishers Pvt. Ltd. 